\title{
Inhomogeneity of Surface Labelling of B-Cells at Prospective Sites of Exocytosis
}

\author{
L. Orci, M. Amherdt, J. Roth ${ }^{1}$, and A. Perrelet \\ Institute of Histology and Embryology, Department of Morphology, University of Geneva Medical School, Geneva, Switzerland
}

\begin{abstract}
Summary. Using ferritin-labelled Ricinus communis agglutinin to detect lectin-binding sites of the pancreatic B-cell surface, we show that limited regions of the plasma membrane are deprived of lectin-binding sites over marginated secretory granules. Such deprived regions increased during glucose stimulation of B-cells in monolayer culture: $56 \pm 8$ of them were found in high $(300 \mathrm{mg} / 100 \mathrm{ml})$ glucose as compared to only $27 \pm 5$ in low $(50 \mathrm{mg} / 100 \mathrm{ml})$ glucose $(\mathrm{p}<0.005)$. In addition, non-membrane, intracytoplasmic bridges were detected between the plasma membrane and the membrane of the marginated granule suggesting the involvement of cell web components in promoting the change in surface labelling.
\end{abstract}

Key words: Membrane, cell coat, lectin-binding sites, exocytosis, cell web, B-cell, islet of Langerhans.

Freeze-fracture has now convincingly established that the morphological counterpart of proteins, i. e. intramembrane particles, are absent from limited areas of the secretory granule and plasma membranes before and during exocytotic fusion in mammalian secretory cells $[4,6,9,15]$, suggesting that fusion takes place between lipid portions of the membranes [1]. In a preliminary note [14] we showed that in addition surface components represented by lectin and anionic-binding sites of the B-cell plasma membrane were absent from limited regions overlying marginated secretory granules prior to fusion. We now report the results of a complete study involving the quantitative evaluation of the distribution of lec1 Present address: Institute of Pathology, Friedrich Schiller Uni-
versity, DDR-69 Jena, GDR tin-binding sites at the B-cell surface under resting and stimulatory conditions [8] of insulin release in monolayer cultures exposed to Ricinus communis agglutinin coupled to ferritin.

\section{Material and Methods}

The Ricinus communis agglutinin ( $\mathrm{RcA}$ ) was purified by affinity chromatography from saline extracts of Ricinus communis beans as described earlier [18]. The coupling of RcA to ferritin was performed by means of the one-step glutaraldehyde technique, using D-galactose for protection of the combining sites of the lectin during conjugation procedure [17].

Monolayer cultures (5-days old) of newborn Wistar rats established as described in [16] were exposed for $2^{1 / 2}$ hours to a low $(50 \mathrm{mg} / 100 \mathrm{ml})$ or high $(300 \mathrm{mg} / 100 \mathrm{ml})$ glucose concentration, then further incubated in the same medium for $10 \mathrm{~min}$ at $37^{\circ} \mathrm{C}$ with a solution of ferritin-labelled RcA. At the end of the incubation period, the labelled cultures were washed in excess culture medium to remove unbound RcA-ferritin conjugate and fixed by the replacement of the medium by with a solution of $2.5 \%$ glutaraldehyde in $0.1 \mathrm{~mol} / 1 \mathrm{Na}$-cacodylate buffer. Fixed cultures were dehydrated in increasing concentration of alcohol and embedded in Epon. Thin sections of embedded cultures were observed in a Philips EM 300 electron microscope (Philips, Eindhoven, The Netherlands) after staining of the sections with uranyl acetate and lead citrate.

The quantitative evaluation of the distribution of RcA-binding sites was carried out as follows: the periphery of endocrine clusters showing the free surface of B-cell plasma membranes (a total of 14 clusters in each 50 and $300 \mathrm{mg} / 100 \mathrm{ml}$ glucose concentration) was photographed at low magnification. Plasma membranes of B-cells facing the intercellular space inside the cluster were not recorded since their accessibility to the RcA-ferritin complexes could not be ascertained. The total length of the free plasma membranes exposed was measured with a curvimeter (Minerva AG, Switzerland). Marginated secretory granules were then photographed in the same areas at higher magnification to detect the presence $(+)$ or absence $(-)$ of ferritin label at the surface of the plasma membrane overlying the marginated granules. In a normally-labelled membrane, ferritin molecules appear regularly arranged at a short distance from the outer leaflet and separated from one another by a space approximately equal to the size of one ferritin particle. We 
Table 1

\begin{tabular}{llll}
\hline $\mathrm{n}=14$ & Glucose 300 & & Glucose 50 \\
\hline $\begin{array}{l}\text { Number of marginated } \\
\beta \text {-granules per } 10 \mu \mathrm{m} \text { of }\end{array}$ & $124 \pm 16$ & $\mathrm{~N} . \mathrm{S}$. & $102 \pm 23$ \\
plasma membrane & & & \\
$\begin{array}{l}\text { Number of }(-) \text { margi- } \\
\text { nated } \beta \text {-granules per } \\
10 \mu \mathrm{m} \text { of plasma mem- } \\
\text { brane }\end{array}$ & $56 \pm 8$ & $\mathrm{p}<0.005$ & $27 \pm 5$ \\
$\begin{array}{l}\text { Number of }(+) \text { margi- } \\
\text { nated } \beta \text {-granules per }\end{array}$ & $67 \pm 10$ & N.S. & $75 \pm 21$ \\
$\begin{array}{l}10 \mu \mathrm{m} \text { of plasma mem- } \\
\text { brane }\end{array}$ & & & \\
$\%$ of $(-)$ marginated & $42 \pm 4$ & $\mathrm{p}<0.05$ & $27 \pm 6$ \\
$\beta$-granules & & & \\
$\%$ of $(+)$ marginated & $58 \pm 4$ & $\mathrm{p}<0.05$ & $73 \pm 6$ \\
$\beta$-granules & & & \\
\hline
\end{tabular}

$(-)=$ Outer leaflet of B-cell plasma membrane over marginated granules deprived of ferritin molecules ${ }^{1}$

$(+)=$ Outer leaflet of B-cell plasma membrane over marginated granules not deprived of ferritin molecules

$\mathrm{n}=$ Number of clusters examined

Glucose 300 and Glucose 50: cultures incubated with $300 \mathrm{mg} /$ $100 \mathrm{ml}$ and $50 \mathrm{mg} / 100 \mathrm{ml}$ glucose respectively

${ }^{1}$ See Material and Methods for the evaluation procedure

considered as absence of ferritin particles any interruption of the surface labelling larger than that corresponding to at least three ferritin particles plus intervening spaces. The length of plasma membrane exposed, the number of marginated secretory granules and the presence or absence of ferritin molecules in the margination zones observed in low and high glucose concentration, were then combined to evaluate and compare several parameters as described below. All measurements were repeated twice by two independent persons not knowing the experimental protocol. The significance of differences between individual quantitative values was assessed by Student's $t$ test.

Freeze-fracture replicas of islet cells shown in Figs. 4 and 5 were obtained from unfixed isolated islets according to the standard procedure of Moor and Mühlethaler [10] with a Balzers freeze-fracture device BAF 301 (Balzers AG, Liechtenstein).

\section{Results}

The periphery of a cluster of endocrine cells in a thin sectioned culture exposed to RcA-ferritin is shown in Fig. 1, revealing the "free" regions of B-cell plasma membranes which were subjected to the evaluation of lectin-binding sites. At higher magnification (Fig. 2), the outer leaflet of the B-cell plasma membrane appears dotted at regular intervals by individual ferritin molecules indicating the lectin ( $\mathrm{RcA})$ binding sites of the membrane. By contrast (Fig. 3), other areas of the B-cell plasma membrane appear devoid locally of ferritin molecules. The deprived areas occur frequently over the membrane of marginated secretory granules, although plasma membrane seemingly at the same distance from the mem- brane of a marginated granule may or may not show this change (compare Figs. 2 and 3).

The number of marginated granules per plasma membrane length, the number of marginated granules covered with a segment of plasma membrane devoid of ferritin molecules and the number of marginated granules covered with a normally-labelled plasma membrane were evaluated in resting and stimulated conditions of insulin release. As shown in Table 1 , the number of marginated $\beta$-granules per $10 \mu \mathrm{m}$ of plasma membrane tended to increase in stimulated B-cells; the number of marginated granules covered with plasma membrane areas deprived of lectin-binding sites was significantly augmented in such cells, whereas the number of marginated granules covered with a fully labelled plasma membrane decreased slightly, but not significantly, in stimulated B-cells as compared to resting cells. A similar, significant trend was observed when the percent of marginated granules covered with a normal or a ferritin-deprived plasma membrane was calculated.

Together with these quantitative changes, a qualitative observation was made at the level of neighbouring plasma and secretory granule membranes at sites of margination but unrelated to the presence or absence of ferritin label. This consisted in several electron-dense bridges extending between the inner leaflet of the plasma membrane and the outer leaflet of the secretory granule membrane (Figs. 2 and 3 ). The nature of these bridges could not be ascertained, but selected images obtained from freeze-fracture replicas exposing side-by-side the plasma and the secretory granule membranes (Figs. 4 and 5) suggest that they are filamentous structures, possibly belonging to the cell web present in the subplasmalemmal region of the B-cell [13].

\section{Discussion}

Conventional thin section and freeze-fracture appearances of exocytosis in stimulated B-cells have been amply documented in the past $[12,15]$. In brief, completed exocytotic fusion, as seen in thin sections, consists of a pocket in the plasma membrane containing a granule core. The pocket represents the granule membrane which has become continuous with the plasma membrane, thus exposing the granule content to the extracellular space [12]. In freeze-fracture, a completed exocytotic fusion takes the form of a circular invagination in the P-face of the plasma membrane containing a protruding, smoothly textured granule core. The characteristic feature of the membrane in the invaginated zone is that it lacks intramembranous particles. This results from the removal of particles in a limited area of the plasma and secretory granule membranes when these two 

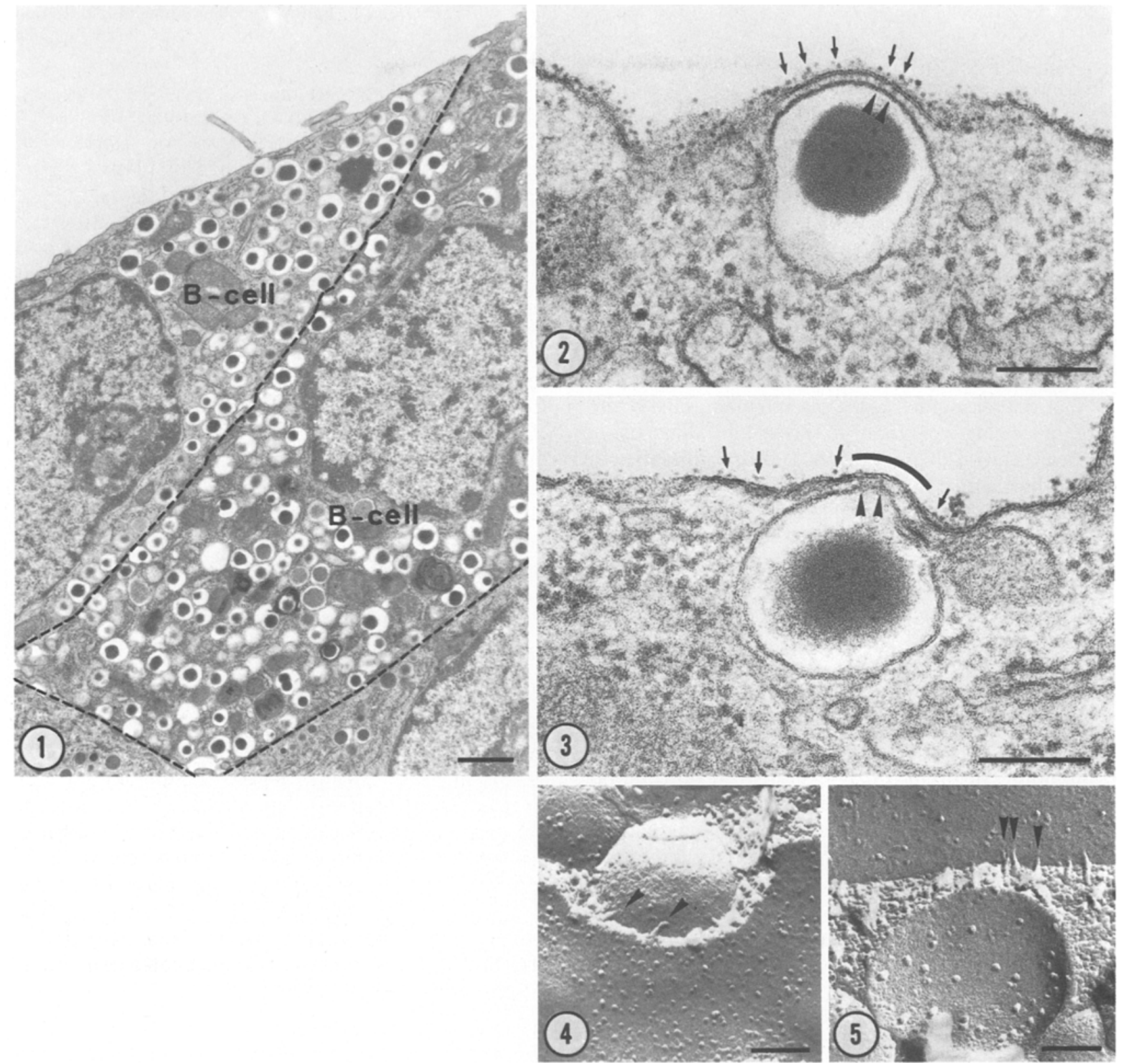

Fig. 12. Periphery of a cluster of cultivated islet cells. The upper part of the cluster corresponds to the "free" surface of a B-cell such as used for the evaluation of lectin-binding sites; the dotted line delimits the surfaces of islet cells facing the inside of the cluster; these faces were not evaluated. X 8700 . The horizontal bar represents $1 \mu \mathrm{m}$

Fig. $2^{2}$. Periphery of a B-cell with a marginated secretory granule. The outer leaflet of the plasma membrane covering the granule is regularly labelled with electron dense ferritin particles (arrows). In register with some of the ferritin particles one sees electron dense bridges (two of them are identified with arrow-heads) between the inner leaflet of the plasma membrane and the outer leaflet of the marginated secretory granule membrane. X 79000 . The horizontal bar represents $0.2 \mu \mathrm{m}$

Fig. $3^{2}$. Periphery of a B-cell with a marginated secretory granule. The outer leaflet of the plasma membrane covering the granule shows a limited area (outlined by the black curved line) from which ferritin particles are absent. A few electron dense bridges (two are indicated by arrow-heads) are visible between the membrane of the secretory granule and the plasma membrane deprived of lectin-binding sites. Arrows indicate ferritin particles outside the deprived area. X 88000 . The horizontal bar represents $0.2 \mu \mathrm{m}$

Fig. $4^{2}$. Freeze-replica of the periphery of an islet cell showing from the outside of the cell the plasma membrane and a secretory granule membrane in close relationship. Arrowheads indicate filamentous structures extending between these two membranes. X 90000 . The horizontal bar represents $0.1 \mu \mathrm{m}$. For identification of the membrane faces in freeze-fracture, see (2)

Fig. $5^{2}$. Freeze-fracture replica of the periphery of an islet cell showing from the inside of the cell a secretory granule membrane in proximity to the plasma membrane. Filamentous elements (arrow-heads) emerge from the space between these two membranes to extend over the plasma membrane. X 91000 . The horizontal bar represents $0.1 \mu \mathrm{m}$. For identification of the membrane faces in freeze-fracture, see (2)

2 For this qualitative illustration of the data, figures were taken indistinctly from low and high glucose incubated cultures 
membranes approach one another at the time of fusion [15].

A novel observation reported in the present study is that comparable areas of the plasma membrane covering marginated secretory granules at prospective sites of fusion frequently appeared devoid of lectin-binding sites as revealed by RcA-ferritin conjugate. In addition, electron-dense bridges in thin section and filamentous structures in freeze-fracture replicas were seen between the inner leaflet of the plasma membrane and the outer leaflet of the membrane of the marginated secretory granule. As described above, one limitation of these observations is that not all regions of the plasma membrane covering marginated $\beta$-granules showed in thin section either electron-dense bridges and/or deprivation of lectin-binding sites. In other words, one could find plasma membrane segments separated by approximately the same distance from the membrane of a secretory granule showing either bridges, lack of ferritin particles, both, or none of these changes.

These differences could have various causes: on the one hand, the small size of ferritin particles and electron-dense bridges may render these structures undetectable since they may not always be properly oriented within the plane of the thin section; on the other hand, it is possible that bridge formation and/ or binding site removal is a shortlived process, not always arrested in a state demonstrable by our technique. None-the-less, the above data extend our knowledge on membrane changes preceding exocytotic fusion.

The removal of surface binding sites from prospective zones of exocytosis has been reported in another cell type, the mastocyte, when challenged to release secretory granules [9]. Results obtained by labelling the anionic sites of the granule membrane with cationized ferritin indicate that the surface of a secretory granule membrane interacting with the plasma membrane is similarly deprived of such sites [7]. Thus, within the time scale of observation, (glyco)protein markers of the membrane, such as particles and binding sites, appear to undergo a simultaneous removal from the interacting membranes, a finding in contrast with reports indicating a dissociation between the movement of surface components and that of intramembranous particles in eukaryotic cells [3]. Involvement of cell web components in the displacement of surface binding sites as recently reviewed by Nicolson [11] is perhaps suggested by the presence of bridges extending between the outer leaflet of the secretory granule membrane and the inner leaflet of the plasma membrane, an observation made previously in another secretory cell in the prefusion stage of exocytosis [5].

Acknowledgements. This work was supported by the Swiss National Science Foundation, grant no 3.120.77.

\section{References}

1. Ahkong, Q. F., Fisher, D., Tampion, W., Lucy, J. A.: Mechanisms of cell fusion. Nature 253, 194-195 (1975)

2. Branton, D., Bullivant, S., Gilula, N. B., Karnovsky, M. J., Moor, H., Mühlethaler, K., Northcote, D. H., Packer, L., Satir, B., Satir, P., Speth, V., Staehelin, L. A., Steere, R. L., Weinstein, R. S.: Freeze-etching nomenclature. Science 190, 54-56 (1975)

3. Bretscher, M. S., Raff, M. C.: Mammalian plasma membranes Nature 258, 43-49 (1975)

4. Chi, E. Y., Lagunoff, D., Koehler, J. K.: Freeze-fracture study of mast cell secretion. Proc. Natl. Acad. Sci. USA 73, 2823-2827 (1976)

5. Franke, W. W., Lüder, M. R., Kartenbeck, J., Zerban, H., Keenan, T. W.: Involvement of vesicle coat material in casein secretion and surface regeneration. J. Cell Biol. 69, 173-195 (1976)

6. Friend, D. S., Orci, L., Perrelet, A., Yanagimachi, R.: Membrane particle changes attending the acrosome reaction in guinea pig spermatozoa. J. Cell Biol. 74, 561-577 (1977)

7. Howell, S. L., Tyhurst, M.: Distribution of anionic sites on surface of B-cell granule and plasma membranes: a study using cationic ferritin. J. Cell Sci. 27, 289-301 (1977)

8. Lambert, A. E., Blondel, B., Kanazawa, Y., Orci, L., Renold, A. E.: Monolayer cell culture of neonatal rat pancreas: light microscopy and evidence for immunoreactive insulin synthesis and release. Endocrinology 90, 239-248 (1972)

9. Lawson, D., Raff, M. C., Gomperts, B., Fewtrell, C., Gilula, N. B.: Molecular events during membrane fusion: a study of exocytosis in rat peritoneal mast cells. J. Cell Biol. 72, 242-259 (1977)

10. Moor, H., Mühlethaler, K.: Fine structure in freeze-etched yeast cells. J. Cell Biol. 17, 609-628 (1963)

11. Nicolson, G. L.: Transmembrane control of receptors on normal and tumor cells. I. Cytoplasmic influence over cell surface components. Biochim. Biophys. Acta 457, 57-108 (1976)

12. Orci, L.: A portrait of the pancreatic B-cell. Diabetologia 10, 163-187 (1974)

13. Orci, L., Gabbay, K. H., Malaisse, W. J.: Pancreatic beta-cell web. Its possible role in insulin secretion. Science 175, 1128-1130 (1972)

14. Orci, L., Malaisse-Lagae, F., Perrelet, A.: Membrane changes during exocytosis in pancreatic B-cells. Diabetologia 13, 423 (Abst.) (1977)

15. Orci, L., Perrelet, A., Friend, D. S.: Freeze-fracture of membrane fusions during exocytosis in pancreatic B-cells. J. Cell Biol. 75, 23-30 (1977)

16. Orci, L., Like, A. A., Amherdt, M., Blondel, B., Kanazawa, Y. Marliss, E. B., Lambert, A. E., Wollheim, C. B., Renold, A. E.: Monolayer cell culture of neonatal rat pancreas: an ultrastructural and biochemical study. J. Ultrastruct. Res. 43, 270-297 (1973)

17. Roth, J., Thoss, K.: The use of fluorescein isothiocyanatelabelled lectins for immuno-histological demonstration of saccharides. I. Methodical investigations with concanavalin A, Lens culinaris lectin and Ricinus communis lectin. Exp. Pathol. (Jena) 10, 258-267 (1975)

18. Roth, J., Wagner, M., Thoss, K.: Wheat germ agglutinin and Ricinus communis agglutinin as specific saccharide stains in light and electron microscopy. Exp. Pathol. (Jena) 11, 67-72 (1975)

Received: February 2, 1978

and in revised form: October 17, 1978

L. Orci

Institute of Histology and Embryology

University of Geneva Medical School

CH-1211 Geneva 4

Switzerland 